\title{
A mozgásterápia szerepe az osteoporosis megelőzősében és kezelésében
}

\author{
PÓSA GABRIELLA, RÓKA ERIKA, KONCSEK KRISZTINA
}

\section{ÖSSZEFOGLALÁS}

A szerzők az osteoporosis mozgásterápiás megelőzési és kezelési lehetőségeire szeretnék felhívni a figyelmet. Az élethossz növekedésével egyre nagyobb kihívást jelent az osteoporosis talaján kialakuló törések szövődményeivel és funkcióvesztésekkel való küzdelem. Általánosan elfogadott az a vélemény, miszerint elengedhetetlenül fontos, hogy ne csak a kialakult problémával vegyük fel a harcot, hanem próbáljuk megelőzni a kialakulásukat. A tanulmány a teljesség igénye nélkül ad betekintést mozgásterápiás eljárásokba, amelyek gyógyszeres terápia mellékhatásai nélkül képesek segíteni a prevencióban és a kezelésben.

\section{Kulcsszavak: $\quad$ Csontsürüség; Fizioterápia; Mozgásterápia; Osteoporosis; Osteoporoticus törés;}

G. Pósa, E. Róka, K. Koncsek: The role of exercise therapy in the prevention and treatment of osteoporosis

The authors would like to draw the attention to the possibilities of prevention and treatment of osteoporosis with exercise therapy. With the increase of life expectancy, it becomes more and more of a challenge to fight against osteoporosis related fracture complications and loss of function. Therefore, the authors consider it essential not only to fight against the emerged problems, but to prevent their development. The study gives an insight into the movement therapies that are able to help in the prevention and treatment without side effects of drug therapy.

Keywords: $\quad$ Bone Density; Exercise - Physiology;

Osteoporosis - Prevention \& control/Therapy;

Osteoporotic fractures - Prevention \& control;

Physical therapy modalities; 


\section{BEVEZETÉS}

A csontritkulás globális egészségügyi probléma, mert a Föld népessége egyre jobban öregszik, emiatt egyre inkább közeledhet egy ebből eredő egészségügyi válság. Becslések szerint az osteoporosis talaján kialakult törések kockázata rövidesen a nők esetében 40\%-ra, a férfiaké 13\%-ra növekszik. A férfiakhoz képest, a nők nagyobb kockázatnak vannak kitéve a csontritkulásban (16). Az osteoporosis előfordulása az Európai Unióban a becslések szerint 27,6 millió volt 2010-ben, ebból 5,6 millió volt férfi (7).

Az osteoporosisnak nemcsak egészségügyi, hanem gazdasági következményei is vannak. $\mathrm{Az}$ összes osteoporosis talaján kialakult törés száma Európában 2,7 millió, ebben mind a férfiak és mind a nők szerepelnek, az ezzel járó közvetlen költség 36 milliárd Euró (13). Az Egyesült Államok 50 év feletti populációjának 10\%-a szenved osteoporosisban. Évről évre növekszik a nők és férfiak körében egyaránt (5). Az osteoporosis talaján kialakuló törések a lakosság egyik fő morbiditási és mortalitási oka. A legtöbb haláleset a csípőtáji törésekből ered, ami az eseményt követő első 3-6 hónapban következik be. Fájdalom és funkció veszteség (ezek tovább növelik az ismétlődő törések számát), majdnem mindig együtt jár a kórházi tartózkodással. A lassú és a gyakran hiányos rehabilitáció miatt a betegek jelentős része tartósan szociális otthonokba kerül (13). Az érintett személyek csupán $40 \%$-a nyeri vissza a törés előtti függetlenségét teljes mértékben (3). Az Egyesült Államokban 243.000 ember él csontritkulással kapcsolatos fogyatékossággal, ezen állapotok oka elsősorban a csigolyatörés (52\%) (26).

$\mathrm{Az}$ osteoporosis olyan betegség, amelyben a csontok törékennyé válnak. Ha nem akadályozzuk meg ezt a folyamatot, akkor a csontritkulás némán $(8,13)$, a legtöbb esetben tüneteket nem mutatva és fájdalommentesen fog kifejlődni. Az esetek többségében csak akkor válik ismertté a jelenléte, amikor a csontvesztés elegendő lesz ahhoz, hogy az osteoporosis talaján kialakuló törése lesz az egyénnek. Az osteoporosis legfeltűnőbb jelei a csonttörés, a fájdalom és a deformitás, de számos más kisebb tünet is társulhat hozzá (6).

\section{Etiológiáját tekintve lehet:}

- életkorból adódó,

- öröklött,

- metabolikus károsodás következménye,

- felszívódási zavar,

- daganat,

- gyógyszeres beavatkozás (5).

\section{Csontvesztés}

Egy 1988-as szakirodalomban még azt írták, hogy a csonttömeg fokozatosan növekszik a negyedik évtizedig, ekkor mindkét nemnél életkorral összefüggő folyamatos csökkenés következik be a csonttömegben, természetesen idetartozik a nőknél a postmenopausalis periódus is (23). Az ezt követő irodalmak már sokkal korábbi időszakot jelölnek meg a csonttömeg növelés életkori maximumának, melyeket már megalapozott kutatások bizonyítanak.

A nők 30-35 éves koruk körül évi 0,5-1\%-ot veszítenek a csonttömegükből, ekkor kezdődik a folyamat, és ez a menopausát követően felgyorsul, akár 3-5\%-os is lehet. Férfiaknál 45-50 éves kor körül kezdődik, 0,5-1\%-os éves csonttömeg vesztéssel (11).

A nők a csonttömegük akár $20 \%$-át elveszítik a menopausát követő 5-7 évben. 50 éves kor felett minden második nő és minden negyedik férfi érintetté válik az osteoporosishoz kapcsolódó töréssel. A csontritkulás megelőzésére hatékonyak az ellenállással és a teherviseléssel végzett gyakorlatok, a megfelelő kalciumbevitellel együtt (8).

Az immobilizáció egy nagyon fontos oka a csontvesztésnek (12). Az immobilizált beteg egy hét ágyban fekvés alatt annyi csontot elveszíthet, mint egyébként egy év alatt. Emiatt az inaktivitást, amikor csak lehetséges, kerülni kell (13). Immobilizáció az életünk bármely szakaszában bekövetkezhet, az idősebbeknél életkorukból adódóan hosszabb ideig tarthat, és nagyobb mértékű lehet a hozzá társuló csontveszteség.

Fontos az osteoporosis megelőzése és kezelése is. Jelenlétének felderítésében segítséget nyújthatnak különböző vizsgálatok osteodensitometria - amivel képet kaphatunk a csontok állapotáról. A BMD (bone mass density) értéket veszik alapul, ebből is a Tscore értéket, ami a csontok ásványianyag tartalmának eltérése a fiatalkori csúcs csonttömeg 
átlagtól, ezt standard deviációjában határozzák meg (28).

\section{ANYAG ÉS MÓDSZER}

\section{A prevenció jelentősége}

Az osteoporosis talaján kialakult törések közül a csípőtáji és a gerincet érintő törések a legveszélyesebbek. Gyakran eredményeznek szekunder szövődményeket, például a megnövekedett kórházi tartózkodás vagy a funkcionális károsodás okozhat járulékos egészségügyi problémákat. Emellett a törések, a szövődmények növelik az egészségügyi költségeket, és nem utolsó sorban növelhetik a másoktól való függést (16), vagyis az önállóság mértéke csökken az érintett egyéneknél.

Beavatkozásként főként farmakológiai módszereket (hormonpótlás, etidronát, alendronát, kalcium és kalcitonin, D-vitamin) alkalmaznak, ezek kutatások szerint hatékonyak és elérhetőnek bizonyulnak $(12,16)$. Albright 1947-ben javasolta a hormonpótló terápia használatát csontritkulásra, már ekkor az osteoporosis megelőzése volt a cél (2). A probléma ezzel a megközelítéssel az, hogy elsősorban az időseket célozzák meg, akiknél a kockázati tényezők széles körben vannak jelen, és ismét a kezelés kerül középpontba, nem a megelőzés vagy a csontritkulás megakadályozása. A nem gyógyszeres terápiának kellene előnyt élveznie, például a kockázati tényezők változtatása, csökkentése hatást gyakorol az idősek elesésére. Close és munkatársai a magas kockázatú populációban (az osteoporosis magas rizikócsoportja - többek között - minden 65 év feletti nő, függetlenül a további rizikófaktoroktól és minden 65 év alatti nő, aki egy vagy több rizikófaktorral bír $(6,17)$ igazolták, hogy megelőző intézkedésekkel statisztikailag szignifikáns módon csökkenthető az esések és a kórházba kerülések száma (16).

A megelőző terápiának magába kell foglalnia a kockázati tényezők elkerülését, azok számának csökkentését, mint például a dohányzás és a túlzott alkoholfogyasztás. A terápia lényeges része az esések megelőzése is, amely az időseknél különösen nagy jelentőséggel bír (7).

$\mathrm{Az}$ állatokon végzett kísérletek alapján is javasolják az erőteljes fizikai aktivitást, mert fokozza a csonttermelést. Ezzel párhuzamosan, az emberek esetén is magasabb csonttömeget találtak a fizikailag aktív fiatal férfiak és sportolók körében. Az idősek esetében a testmozgás célja, hogy megakadályozzuk a csontvesztést, amely leggyakrabban az életkorból és a menopausából adódik (23).

A jelenlegi adatok azt mutatják, hogy a fiatal nők még növelhetik csúcs-csonttömegüket, ezzel elősegítve hosszú távon a csontok egészségét és a kockázatok csökkenését (16).

\section{Három fö komponens szükséges a megfelelö prevencióhoz:}

\section{- megfelelő étrend}

- megfelelő izomerő, testmozgás, testtartás

- megfelelő életmód $(11,16)$.

A táplálkozással és a mozgásterápiával el kell érni, hogy ezen életmódváltozások, mint például a kalcium ( $\mathrm{Ca}$ ) bevitel növelése, a helytelen testtartás javítása, a helyes emelési és esési technikák tanítása segítsék az egyéneket a megelőzésben. Ezek a prevencióra vagy a csonttömeg-vesztés visszafordítására, valamint a funkcionális képességek megőrzésére irányulnak (11).

A prevenció azért elsődleges fontosságú, mert az osteoporosisnak visszafordíthatatlan hatásai is vannak a szervezetben és magas az aránya az elhúzódó szövődményeknek. Az ideális prevenció testmozgással célozza meg a törések kialakulását a csontok tömegének növelésével, az egyensúly fejlesztésével, az izomerő, a járás, a flexibilitás, a reakcióidő fejlesztésével és az elesés előfordulásának csökkentésével. Ezen paraméterek javítása csökkenti a törési rizikót a gyakorlatokon keresztül (11).

$\mathrm{Az}$ elsődleges prevenció az élet korai szakaszában - ismerten kritikus időszak - a gyermekkorban és a serdülőkorban (maximális a csontok kalcium tartalma), legfeljebb körülbelül 30 éves korig valósulhat meg. Ebben a szakaszban a cél a csúcs-csonttömeg kialakítása. A másodlagos prevenció az élet későbbi szakaszában jelenik meg, amely megcélozza a csontvesztés csökkenését (9). A harmadlagos prevenció az időseket célozza meg, akik már a magas kockázatú személyek közé sorolhatók (4). 


\section{Elsődleges prevenció}

Fiatal felnőttkorra a maximális csúcs-csonttömeg elérése a cél. A legerősebb csontok kialakítása gyermekkorban és serdülőkorban lehetséges. Az ezzel kapcsolatos oktatást már gyermekkorban meg kell kezdeni. Ez hatékony módja annak, hogy megakadályozzuk az osteoporosist és az annak talaján kialakuló töréseket $(6,10)$. Ezek az évek (9-18 év) rendkívül fontosak a fizikai és a pszichés fejlődés szempontjából is, ebben az életszakaszban, a kamaszkor végére kialakul az össz-csonttömeg 90\%-a $(16,24)$.

Jelenleg $12 \pm 19$ év közötti lányok 85\%-a nem fogyasztja el az ajánlott napi Ca mennyiséget, ami az ideális szerkezetű, erős csontok fejlődéséhez szükséges. A megfelelő mennyiségű Ca fogyasztása mellett fontos a fizikai aktivitás. A lányokra egységesen elmondható, hogy kevésbé vesznek részt olyan intenzív testmozgásban, ami megerősítené a csontjaikat is. Ezt lehet orvosolni a célzott oktatással és a helyes egészségmagatartás megtanításával (16).

A fiatalokban a testmozgás és a sport jótékony hatással bír, a csontot ösztönözik a fejlődésre, és tartalékot halmoznak fel (23). Ebben az életkorban lehet beépíteni és megerősíteni az egészséges szokásokat, mint például a megnövekedett Ca bevitelt, a fokozott testmozgást, és megtanítani nekik az egészségtudatos viselkedést: többek között a dohányzás és az alkoholfogyasztás elkerülésének fontosságát. Ezen elsajátított ismeretek remélhetőleg hatást gyakorolnak felnőttkori egészségmagatartásra is. Elengedhetetlen, hogy ezekben a programokban a szülők képzése is megjelenjen, hiszen így válhatnak igazán a program támaszává (16).

Feladatok gyermek- és serdülőkorban:

- biztosítani kell a megfelelő mennyiségú $\mathrm{Ca}$ bevitelt (étrendi ajánlások az országban vagy régióban),

- figyelni kell az alultápláltság és kiemelten a fehérje alultápláltság elkerülésére,

- biztosítani kell a megfelelő mennyiségú D-vitamint (természetben töltött idő, így a nap hatását kihasználva vagy táplálékkiegészítővel),

- növelni kell a fizikai aktivitás szintjét,

- kerülni kell a dohányzást,

- tájékoztatni kell őket a magas alkoholfogyasztás kockázatáról (10).

\section{Másodlagos prevenció}

Felnőttkorban a minél magasabb csúcscsonttömeg megtartása a cél, ezzel alacsonyabb lesz a csontritkulás kialakulásának kockázata és az ezzel kapcsolatos szövődmények megjelenése. A csúcs-csonttömeg kialakulását követően remodelling szakasz jellemző a csontokra. Ez egy állandó folyamat, ahol a régi csont felszívódik, és új csont képződik (10).

A megelőzés és a kezelés csontritkulás esetén - menopausa után - az életmódbeli tanácsadás, az esés-prevenció és a gyógyszeres terápia lehet. Ezeket mind egyénileg kell meghatározni. Az életkor és a kísérő betegségek mindenképp hatást gyakorolnak a választott terápiára. Azoknál javasolják a hormonpótló gyógyszer használatát, akiknél jelentősek a klimaxhoz kapcsolódó tünetek, rövid ideig és a lehető legalacsonyabb dózisban (2). A gyógyszeres kezelések lehetséges, különböző mellékhatásai miatt az emberek többsége vonakodik használni azokat megelőzésre, így a táplálkozási és testmozgásos preventív és terápiás intézkedések jelennek meg, mint biztonságos és vonzó lehetőségek (23).

\section{Harmadlagos prevenció}

Itt elsődleges cél az osteoporosis kialakulásának, súlyosbodásának megakadályozása, az elesés bekövetkezésének csökkentése és a funkciók megőrzése (24). Néhány kockázati tényező, ami miatt az idősek eleshetnek: csökkent izomerő, testtartási instabilitás, látásromlás, bizonyos gyógyszerek, amelyek szédülést, álmosságot okoznak, valamint veszélyek lakáson belül és kívül (10). Ilyen veszélyes környezeti tényezők lehetnek, csúszós vagy egyenetlen padló, szőnyeg szélei és a rossz vagy nem megfelelő lábbeli. Az esésmentes, biztonságos otthon kialakítása a cél. Egyes gyógyszerek, különösen a nyugtatók, ronthatják az egyensúlyt, jelentős kockázati tényezők törések bekövetkezésénél. Ha lehetséges, akkor azokat a gyógyszereket, amelyek gyorsítják a csontvesztést, el kell kerülni vagy a lehető legkisebb hatásos dózist kell alkalmazni belőlük (7).

Számos szakirodalom szerint a fizikai aktivitás gátolhatja az időskori csontvesztést és még növelni is képes a csonttömeget. A gyakorlatoknak alkalmazkodnia kell az egyén életkorához, a fizikai képességeihez és a csontozat 
állapotához (23).

Idősek esetén, akiknél bizonyos mennyiségű csonttömeg elvesztése már jelen van, és különböző mértékű mozgásszegény élet, esetleg társbetegségek megjelentek, ott az erőteljes testmozgás ellenjavallt. A mozgásprogram ilyen esetekben a helyes testtartás kialakítása, az isometricus erősítő gyakorlatok a gerinc körül. Ajánlott a séta - amely a legegyszerűbb formája a testtömegterheléssel járó gyakorlatoknak - az úszás, a napi tevékenységek elvégzése, társas tánc és csoportos gyakorlatok (csak olyan gyakorlatokkal, amik közvetlen kontroll nélkül biztonsággal kivitelezhetőek), amelyek ösztönzőleg hatnak és alkalmazkodnak az életkorhoz (23).

\section{Táplálkozás}

- A D-vitamin-kiegészítők csökkentik az esésből következő törés kockázatát, feltéve, ha a napi D vitamin adag több mint 700 NE (13).

- Legalább 1000 mg / nap Ca, 400-800 NE D-vitamint és $1 \mathrm{~g} /$ testtömeg-kg fehérje bevitele javallott (7), 71 év felett 1200 mg / nap az ajánlott mennyiség a kalciumból (3). A megfelelő mennyiségű fehérje bevitele szükséges ahhoz, hogy a mozgató szervrendszerben fenn tudjuk tartani a funkciót. Képesek arra is, hogy jelentősen csökkentsék a szövődmények arányát, például a decubitust, súlyos anémiát és társuló tüdő- vagy vesefertőzést. A kórházi tartózkodás hosszát rövidíthetik idős csípőtáji töréssel rendelkező betegeknél (13).

\section{Az osteoporosis mozgásterápiás kezelése}

A teherviseléssel járó gyakorlatok a legkedvezőbbek a csontok egészségének megőrzésében, a testmozgási formák szerves részét képezik a kezelésnek. A fizioterápia fontos eleme a törés utáni rehabilitációnak is (13).

Minden esetben van létjogosultsága a mozgásterápiának, a nagyobb izomerőnek szerepe lehet az esés prevencióban a magabiztosság és a koordináció javulásán keresztül, valamint fenntartja a csonttömeget a csontképződés stimulálásával és a csont resorptio csökkentésével (13).

A fizikai aktivitás döntő szerepet játszik az - osteoporosis talaján keletkezett - csigolyatöréses betegek rehabilitációjában. Extensios vagy isometricus hát- és hasizom erősítésre irányuló gyakorlatok hasznosak, csökkentik annak lehetőségét, hogy további törések alakuljanak ki. A flexiós gyakorlatok ilyen esetben károsak a csigolyatestekre nézve (23). Az akut csigolyatörések vagy krónikus fájdalom esetén használható füző, korzett, ami segít a fájdalom csökkentésében és testtartás javításában, csökkenti a posturalis kilengést, így az esések kockázatát, valamint hozzájárul az életminőség javulásához (21). Hosszú távú, tartós használata viszont izomgyengeséghez vezet (3).

A következő mozgásterápiás lehetőségek állnak rendelkezésünkre:

\section{Erőteljes intenzitású, teherviseléssel járó gyakorlatok}

Olyan gyakorlatok, amelyek a csontokat építik és megtartják azok erejét. Ha korábban volt már csontritkulás miatt kialakult törése az egyénnek, vagy fennáll a csonttörés veszélye, akkor lehetőleg kerülje ezen típusú gyakorlatokat.

Ajánlás pácienseknek: ha nem biztos benne, hogy végezheti ezt a gyakorlatanyagot, akkor kérdezze meg az egészségügyi szakembereket.

Ilyen típusú mozgások lehetnek a következők: tánc, magas intenzitású aerobik, túrázás, kocogás / futás, ugráló kötelezés, lépcsőzés, tenisz.

A lehető legtöbbször végezzen a páciens ilyen típusú gyakorlatokat, akár a hét minden napján, legalább 30 perc (egy 30 perces foglalkozás vagy több részre osztva a nap folyamán) (19).

\section{Alacsonyabb intenzitású, teherviseléssel járó gyakorlatok}

Olyan gyakorlatok, amelyek segítenek megőrizni a csontok erejét és biztonságos alternatívát adnak, ha nem végezhető az erőteljesebb hatású gyakorlat típus.

Ennek a gyakorlattípusnak megfelelnek a következők: elliptikus tréner használata, alacsony intenzitású aerobik, lépcsőző gépek, gyors séta a futópadon vagy a szabadban.

\section{Izomerösítő gyakorlatok}

Ezek olyan gyakorlatok, ahol testmozgást végzünk gravitációval szemben, súlyokat vagy 
más ellenállást felhasználva (19). Az izomerősítés javítja a mozgékonyságot, az erőt, a testtartást és az egyensúlyt, ami összességében csökkentheti az elesés kockázatát (20).

Néhány gyakorlat, ami megfelelő erősítésnek: súlyok emelése, elasztikus szalagokkal végzett gyakorlatok, konditermek gépei, saját testsúllyal végzett gyakorlatok, funkcionális mozgások.

A jóga és a pilates is növeli az izomerőt, az egyensúlyt és a rugalmasságot. Azonban egyes gyakorlatok nem biztonságosak a csontritkulásban szenvedőknek vagy olyanoknál, akiknél fokozottan fordul elő csonttörés. Például, az előre hajlással járó gyakorlatok növelhetik az esélyét a kompressziós csigolyatörésnek. A gyógytornász feladata, hogy tájékoztatást adjon, mely gyakorlatok biztonságosak és megfelelőek (19). Kerüljék az előre hajlással járó mozgásokat és figyeljenek arra, hogy rotációval ne kombinálják (3). Két-három nap hetente, alacsonyabb ismétlésszám egyszerre, ne csak egy testrészt célozzon meg naponta (19).

\section{Ütközés nélküli (non- impact) gyakorlatok}

Alkalmasak az egyensúly, illetve a testtartás javítására és segítenek a mindennapi tevékenységek (házimunka, kertészkedés) (3) kivitelezésében. Alkalmasak az izomerő növelésére és csökkentik az esések kockázatát, továbbá a csonttörések bekövetkezését.

Azok az egyensúlyfejlesztő gyakorlatok, amik erősítik az alsó végtag izmait is - például a Tai Chi - csökkenthetik az esések kockázatát (20).

Elengedhetetlenül fontosak a testtartás javító gyakorlatok, amelyek többek között csökkentik annak az esélyét, hogy eltörjenek a csontok, különösen a gerinc, illetve a csigolyák. A funkcionális gyakorlatok segítenek a mindennapi tevékenységekben és csökkentik az elesés és törés esélyét. Például, ha nehézkes a székből való felállás vagy lépcsőzés, akkor ezekhez kapcsolódó gyakorlatokat végeztetünk (19).

Ilyen típusú gyakorlatokat a hét minden napján végezhet az érintett egyén, vagy olyan gyakran, ahogy szükséges. Lehet összpontosítani egy-egy területre (19). Нa figyelembe vesszük azt, hogy időskorban előfordulnak különböző ízületi érintettségek, például csípőízületet érintő gyulladásos vagy degeneratív kórképek, akkor ezek hatást gyakorolnak az egyensúlyra, hiszen szignifikánsan megnő a testtömegközéppont kilengése (27). Ha ez előfordul, akkor elesik, vagy elveszti az egyensúlyát a páciens, ilyen esetben több időt fordítunk az egyensúlyi gyakorlatokra (19).

\section{EREDMÉNYEK}

A mozgásterápia eredményeit az osteoporosisban a következő tanulmányokon keresztül vizsgálhatjuk.

Hernlund szerint nem bizonyított, hogy $\mathrm{mi}$ minősül optimális gyakorlati programnak osteoporosis szempontjából, mi az, ami fenntartja az egészséges csonttömeget. Ezzel párhuzamban viszont azt mondja, hogy a testmozgás hasznos, hiszen javítja a testtartást és az egyensúlyt, ami véd az esésektől és törésektől (7).

Sinaki vizsgálatából kiderül, hogy a csontritkulásban szenvedő nőknek a fokozott háti kyphosisához gyengébb thoracalis extensor és gyengébb alsó végtagi izomerő társul, amit lassabb járás, rossz egyensúly kísér, mindezek növelik az esés kockázatát. Ezért a terápiát ki kell terjeszteni az egyensúly javítására (25).

Nagy és munkatársai egyik korábbi tanulmányukban idősekkel végeztettek egyensúlyi tréninget, míg a funkcionális teljesítményben szignifikáns javulást tapasztaltak (Time Up and Go teszt), addig a tréninget követően szignifikánsan nagyobb kilengést regisztráltak mediolateralis (ML) irányba. Eredményeik felvetették, hogy a résztvevők magabiztossága javult a tréning hatására az egyensúlyi helyzetekben, ML irányban (18).

Más közlemények viszont kimutatták, hogy a fizikai aktivitás csökkenti az elesések és ezzel együtt a csípőtáji törések számát a menopausán átesett nőknél. Emellett viszont azt is megállapították tanulmányukban, hogy a legtöbb nő nehezen fogad el és tart be egy konkrét testmozgással járó programot (22).

Számos tanulmány számol be a testmozgás csonttömegre gyakorolt jótékony hatásáról. Csökkenti a csontveszteséget és növeli a csont ásványianyag tartalmát, a csont kalcium indexét, a test teljes kalcium tartalmát, a gerinc BMD értékét. Ezekben a tanulmányokban vizsgálták a nőket és a férfiakat, az időseket és a fiatalokat, osteoporosis jelenlétében és 
anélkül. A mozgásterápia hatását a femuron vizsgálták. Nem szignifikáns eredményt kaptak, de azt találták, hogy a BMD értéke magasabb volt a gyakorlatot végzők körében, mint a nem tornázó csoportnál. Arról számoltak be, hogy a séta és a testsúlyterheléssel járó aerob tréning nagyobb hatást gyakorolt a gerincre és az alsó testfél BMD értékére (11).

Az Egyesült Államokban 1995-ben kezdődött egy felmérés, azt vizsgálták, hogy miként változtatja meg a BMD értékét az erőnléti mozgás a megfelelő Ca bevitellel kombinálva postmenopausa jelenlétében. Két csoportot alakítottak ki: hormonpótlásban részesültek vagy sem. Mozgásszegény életmódnak a hetente 120 percnél kevesebb fizikai aktivitást vették. Véletlenszerúen döntötték el, kik tartoztak a kontrollcsoportba és kik a mozgásterápiás csoportba. A tanulmányban résztvevő nők soha nem vettek részt hasonló felmérésben. A vizsgálatban minden résztvevő $800 \mathrm{mg}$ kalcium-citrát kiegészítőt fogyasztott (Citracal 1) naponta. A felmérésben kétszázhatvanhat 45 és 65 éves nő vett részt (8).

A kontrollcsoport megőrizte mozgásszegény életmódját, míg a fizikai aktivitásban közremúködők felügyelet melletti, csoportban végzett tornaalkalmakon vettek részt. Teherviselő és ellenállással járó gyakorlatokat végeztek 30 napon keresztül úgy, hogy egymást követő napon nem volt tréning (8).

$\mathrm{Az}$ első évben az edzések 60-75 percig tartottak, benne bemelegítés ( 5 perc), izomerősítés (20+5 perc), keringést fokozó és teherviselő gyakorlatok (15 perc), végül levezetés. Mérsékelt hatású gyakorlatokat alkalmaztak felügyelet mellett (pl.: gyaloglás, jogging, ugrálás és ugrálókötelezés), a maximális pulzusszám 70\%-80\% (pl.: lépcsőzés step padon) és a gyakorlatok tartalmaztak nyújtó és egyensúlyi feladatokat is (8).

Erősítés során sor került súlyzók és gépek használatára is. A gépekkel végzett gyakorlatok középpontjában a főbb izmok álltak pl.: ergométeres evezés, különböző guggolás típusok, hátizom erősítés, törzs rotációs gyakorlatok.

Egy év hatása a BMD értékére:

Az első év eredményei bizonyították, hogy a testmozgást végző csoport résztvevőinek BMD értéke szignifikánsan javult.

Hormonpótláson átesettek:
- A hormonpótlás, a kalcium-kiegészítők és a testmozgás együttese növelte a trochanter táji BMD értéket körülbelül 1-2\%-kal.

- Hormonpótlásban és kalcium-kiegészítőkben részesülő, de testmozgást nem végzők csoportjánál elhanyagolható változás volt a BMD értékében.

Hormonpótlásban nem részesültek:

- Nem volt hormonpótlás, kalcium-kiegészítőket kaptak és testmozgást végeztek, itt növekedést találtak trochanter táji BMD értékben, mintegy $1 \%$-ot.

Nem volt hormonpótlás, nem volt testmozgás, kalcium-kiegészítőket kaptak, emellett a terápia mellett szignifikánsan csökkent a BMD (8).

Egy kutatásban kilenc menopausa utáni nő vett részt, hetente háromszor egy óra testmozgást végeztek (bemelegítő, kondicionáló és keringést javító gyakorlatok). Egy év után növekedést tapasztaltak a test össz-kalcium szintjében, míg csökkenés volt megfigyelhető egy 9 fős mozgásszegény életet élő nőkből álló csoportban. Nem szignifikáns változásokat találtak a csont ásványianyag tartalmában (1).

Egy másik programban Simkin és munkatársai dinamikus terheléses gyakorlatokat végeztettek, 14 menopausán átesett nő (53-74 éves) vett részt benne, 5 hónapig tréningeztek hetente háromszor. $\mathrm{Az}$ átlagos csontsűrűség 3,8\%-os növekedést mutatott, a kontrollcsoportnál 1,9\%-os csökkenést találtak (23).

Smith és munkatársai felmérésében 65-69 éves nők vettek részt, napi 30 perces könnyű vagy mérsékelt fizikai aktivitással járó tornaprogramot végeztek, egy héten 3 alkalommal. 36 hónapon keresztül tartott, 4,2\%-os növekedést mértek a csont ásványianyag tartalmában a radius distalis végén, a kontrollcsoportban ugyanez 2,5\%-os csökkenést mutatott (23).

A testmozgás preventív hatását vizsgálták egy edzésprogram során, amelyet hetente kétszer egy óra hosszában, 8 hónapon keresztül végeztek a vizsgálati alanyok. Az ágyéki gerinc ásványi csonttartalmában 3,5\%-os növekedést tapasztaltak a mozgásterápiás csoportnál, míg 2,7\%-os csontvesztést az inaktív kontrollcsoportnál (15).

A megerőltető testmozgás káros hatásait figyelték meg fiatal női sportolóknál, intenzív testedzés hatására amenorrhoea mellett csökkent a testtömegük és a zsírszövetük is. Komoly 
fogyás alakult ki az axiális csont denzitásban és szekunder típusú alacsony ösztrogénszintű állapot következett be. Az intenzitás csökkentésével újra kezdődött a menstruáció és markáns növekedés következett be a testtömegben és a csigolyák csontsűrűségében, de lemaradást mutatott a korosztályukhoz képest. A fokozatosság előnyösebb ebben az esetben is (14, 23).

\section{MEGBESZÉLÉS}

A töréseket meg lehet előzni, a csontvesztés mértékét lehet csökkenteni, akár a folyamatot meg is tudjuk állítani, ehhez egész életen át tartó szokásokat kell bevezetni és ezeket az élet végéig megtartani. Általában idősebb nőkhöz társítják ezt a betegséget, de nem csak az ő korosztályukban van teendő. $A z$ erös csontok felépitését, kialakitását gyermekés serdülökorban el kell kezdeni és azt az egész felnőtt életben meg kell tartani. Jelenleg nincs orvosi eszköz, amivel vissza tudnánk fordítani a csontritkulást és annak következményeit, így a leghatékonyabb módszer a megelőzés, egészségnevelésen keresztül (16).

Akik a veszélyeztetett csoportba tartoznak, azokat meg kell tanítani arra, hogy a mindennapi tevékenységeiket hogyan végezzék minimális erőfeszítéssel. Fontos megtanítani a helyes testtartást, meg kell erősíteni az izmokat és fejleszteni kell a koordinációt folyamatos mérsékelt testmozgáson keresztül. Szociális szempontból ezek nem elhanyagolható lépések. Multiprofesszionális csapatnak kell együttmúködni ebben, köztük orvosok, ápolók, gyógytornászok, a foglalkoztatási és rekreációs terapeuták, szociális munkások és dietetikusok $(3,23)$.

A folyamatos fizikai aktivitás hatására javul az általános fizikai teljesítmény, a jólét, és társadalmi hatása is van. Hasznos lehet minden korosztály számára az osteoporosis megelőzésére és kezelésére (23). 


\section{IRODALOM}

1. Aloia J. F., Cohn S. H., Ostuni J. A., Cane R., Ellis K.: Prevention of involutional bone loss by exercise. Ann. Intern. Med. 1978. 89. (3): 356-358. https://doi.org/10.7326/0003-4819-89-3-356

2. Brixen K., Abrahamsen B., Kassem M.: Prevention and treatment of osteoporosis in women. Curr. Obstetr. Gynaecol. 2005. 15. 251-258. https:// doi.org/10.1016/j.curobgyn.2005.05.003

3. Cosman F., de Beur S. J., LeBoff M. S., Lewiecki E.M., Tanner B., Randall S., Lindsay R.; National Osteoporosis Foundation: Clinician's guide to prevention and treatment of osteoporosis. Osteoporos. Int. $2014.25 . \quad(10)$ : $2359-2381$. https://doi.orq/10.1007/s00198-014-2794-2

4. Dontas I. A., Yiannakopoulos C. K.: Risk factors and prevention of osteoporosis-related fractures. J. Musculoskelet. Neuronal Interact. 2007.7. (3): 268-272.

5. Gallagher T. C., Geling O., Comite F.: Missed opportunities for prevention of osteoporotic fracture. Arch. Intern. Med. 2002. 162. (4): 450-456. https://doi.org/10.1001/archinte.162.4.450

6. Goodman C. C., Snyder T. K.: Differential diagnosis for physical therapists: Screening for referral. 5. ed. Philadelphia, Saunders. 2012. 816 p.

7. Hernlund E., Svedbom A., Ivergård M., Compston J., Cooper C., Stenmark J., McCloskey E. V., Jönsson B., Kanis J. A.: Osteoporosis in the European Union: medical management, epidemiology and economic burden. A report prepared in collaboration with the International Osteoporosis Foundation (IOF) and the European Federation of Pharmaceutical Industry Associations (EFPIA). Arch. Osteoporos. 2013. 8: 136. https:// doi.org/10.1007/s11657-013-0136-1

8. Houtkooper L. B., Stanford V. A., Metcalfe L. L., Lohman T. G., Going S. B.: Preventing osteoporosis the Bone Estrogen Strength Training way. ACSM's Health \& Fitness Journal, 2007. 7. (1): 21-27. https://doi.orq/10.1249/01. FIT.0000257708.14987.38

9. Ilich J. Z., Badenhop N. E., Matkovic V.: Primary prevention of osteoporosis: Pediatric approach to disease of the elderly. Womens Health Issues. 1996. 6. (4): 194-203. https://doi.orq/10.1016/1049-3867(95)00077-1

10. International Osteoporosis Foundation: Preventing osteoporosis. Women's health medicine. 2006. 3. 4. $155-156$.

11. Lewis C. B., Knortz K. A.: Orthopaedic assessment and treatment of the geriatric patient. Mosby. 1993. 424 p.

12. Kanis J. A.; World Health Organization: Assessment of fracture risk and its application to screening for postmenopausal osteoporosis: Synopsis of a WHO report. Who Study Document. Osteoporosis International. $1994.4 . \quad$ (6): $368-381$. https://doi.org/10.1007/BF01622200

13. Kanis J., Burlet N., Cooper C., Delmas P. D., Reginster J. Y., Borgstrom F., Rizzoli R.: European guidance for the diagnosis and management of osteoporosis in postmenopausal osteoporosis. Osteoporos. Int. $2008 . \quad 19 . \quad$ (4): $399-428$. https://doi.orq/10.1007/s00198-008-0560-z

14. Keen A. D., Drinkwater B. L.: Irreversible bone loss in former amenorrheic athletes. Osteoporos Int. 1997. 7. (4): 311-315. https://doi.orq/10.1007/BF01623770

15. Krølner B., Toft B., Nielsen S. P., Tondevald E.: Physical exercise as prophylaxis against involutional vertebral bone loss: a controlled trial. Clin. Sci. 1983. 64: 541-546. https://doi.org/10.1042/cs0640541

16. Mark S., Link H.: Reducing osteoporosis: prevention during childhood and adolescence. Bulletin of the World Health Organization, 1999.17. 423-425.

17. Michlovitz S. L., Nolan T. P.: Modalities for therapeutic intervention. 4. ed. F. A. Davis Co. 2005. 309 p.

18. Nagy E., Feher-Kiss A., Barnai M., Domján-Preszner A., Angyan L., Horvath G.: Postural control in elderly subjects participating in balance training. Eur. J. Appl. Physiol. 2007. 100. (1): 97-104. https://doi.ora/10.1007/s00421-007-0407-x

19. National Osteoporosis Foundation. Accessed 2016-02. http://nof.org/

20. National Osteoporosis Foundation: Clinician's guide to prevention and treatment of osteoporosis. Washington, DC. National Osteoporosis Foundation, 2010.

21. Pfeifer M., Begerow B., Minne H. W.: Effects of a new spinal orthosis on posture, trunk strength, and quality of life in women with postmenopausal osteoporosis: a randomized trial. Am. J. Phys. Med. Rehabil. 2004.83. (3): $177-186$. https://doi.ora/10.1097/01.PHM.0000113403.16617.93

22. Raab C. A., Gregerson D., Shaw J. M., Snow C.: Postmenopausal women take steps to reduce their osteoporosis risk. Womens H ealth Issues. 1999. 9. (4): 211-218. https://doi.org/10.1016/S1049-3867(99)00007-9

23. Schapira D.: Physical exercise in the prevention and treatment of osteoporosis: a review. J. Roy. Soc. Med. 1988. 81. (8): 461-463.

24. Schrager S.: Osteoporosis prevention in primary care. Wisconsin Medical Journal. 2003. 102. (3): 52-56.

25. Sinaki M., Brey R. H., Hughes C. A., Larson D. R., Kaufman K. R.: Balance disorder and increased risk of falls in osteoporosis and kyphosis: significance of kyphotic posture and muscle strength. Osteoporos. Int. 2005.16 : $1004-1010$. https://doi.org/10.1007/s00198-004-1791-2

26. Siris E. S., Miller P. D., Barrett-Connor E., Faulkner K. G., Wehren L. E., Abbott T. A., Berger M. L., Santora A. C., Sherwood L. M.: Identification and fracture outcomes of undiagnosed low bone mineral density in postmenopausal women: results from the National Osteoporosis Risk Assessment. JAMA. 2001. 286. (22): 2815-2822. https://doi.org/10.1001/jama.286.22.2815

27. Sziver E., Nagy E., Preszner-Domjan A., Posa G., Horvath G., Balog A., Toth K.: Postural control in degenerative diseases of the hip joint. Clin. Biomechan. 2016. 35: 1-6. https://doi.org/10.1016/j.clinbiomech.2016.04.001

28. WHO Scientific Group on the Prevention and Management of Osteoporosis: Prevention and management of osteoporosis. Technical Report Series. 2003. $206 p$.

\section{Pósa Gabriella}

Szegedi Tudományegyetem, Egészségtudományi és Szociális Képzési Kar, Fizioterápiás Tanszék 6726 Szeged, Temesvári krt. 31. 